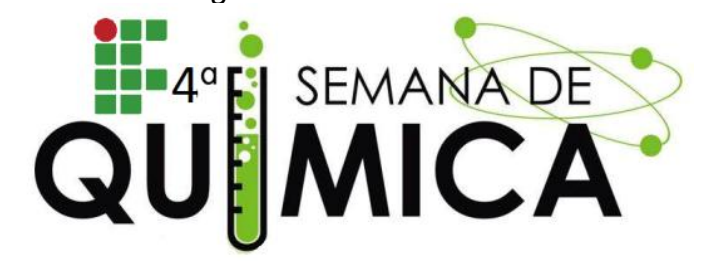

\title{
A IMPORTÂNCIA DA PROMOÇÃO DE AULAS DIVERSIFICADAS NO ENSINO DA QUÍMICA
}

\author{
LEMOS, P. H. M. (IFRN), OLIVEIRA, J. B. S.(IFRN), SOUZA, L. G. S (Orientador, IFRN)
}

Palavras Chave: Ensino de Química, Metodologias Diversificadas, Aprendizagem.

\section{INTRODUÇÃO}

O uso de metodologias tradicionais são, na maioria das vezes, os mais utilizados por professores para a explanação de conteúdos em diferentes disciplinas. No entanto, tais metodologias nem sempre levam em consideração as várias dimensões da prática educativa, nem tão pouco a diversidade de saberes e conhecimentos dos sujeitos. Diante disto, este trabalho tem por objetivo refletir acerca da importância de estratégias metodológicas diversificadas para o ensino da disciplina de química, cuja finalidade é despertar o interesse dos alunos para a disciplina, de modo que o conteúdo trabalhado possa ser compreendido de forma envolvente e dinâmica, despertando assim o interesse pela disciplina.

\section{METODOLOGIA}

Para o desenvolvimento deste trabalho foi realizada uma pesquisa bibliográfica em livros, revista online, artigos e nos Parâmetros Curriculares Nacionais ( $P C N^{\prime}$ 's) sobre o assunto abordado, no qual foram feitas leituras que embasaram na fundamentação teórica deste trabalho.

\section{RESULTADOS E DISCUSSÕES}

Sabemos que a escola foi ao longo dos tempos sofrendo alterações, entre elas, o uso de diferentes métodos de ensino. Hoje, é possível visualizar uma diversidade maior de metodologias e concepções de ensino e aprendizagem. $O$ aluno passou a ser considerado um sujeito ativo e o professor não mais o único detentor do saber. Para Leal (2000), a educação e formação do docente está permeada por algumas dimensões educativas que são significativas na prática de todo educador.

Todas as mudanças na escola trouxeram também transformações na ação docente. Os profissionais reconhecem a importância do planejamento na sua prática diária, a necessidade de busca inovar suas aulas e o uso de diferentes recursos didáticos-pedagógicos. No ensino de química não é diferente, aulas práticas e de campo, jogos educativos e a contextualização dos conteúdos, tem despertado nos estudantes um novo olhar para a disciplina.

Vale ressaltar também, que é necessário que o educador seja sempre um pesquisador. Segundo Demo (2011) é preciso que todo "profissional da educação seja pesquisador, ou seja, maneje a pesquisa como princípio científico educativo e a tenha como atitude cotidiana" (p.2).

\section{CONCLUSÃO}

Diante das considerações acima, verificou-se que há uma necessidade de avançar em práticas de ensino que possam ir além de uma educação tradicional. Percebe-se que o ser humano possui singularidades muito específicas e formas de aprendizagem particulares e que novos recursos na educação devem ser explorados e adotados para que a química possa ser explanada de forma mais categórica, lúdica e atraente possível.

\section{REFERÊNCIAS}

${ }^{1}$ DEMO, Pedro. Educar pela pesquisa. 9. ed. Revista- Campinas, SP: Autores Associados, 2011.

${ }^{2}$ LEAL, Regina Barros. As dimensões educativas. $2000 . \quad$ Disponível em:

<HTTP//rieoei.org/deloslectores/Barros.PDF>. Acesso em: 27 jul.2016. 